\title{
MANFAAT SUPLEMENTASI VITAMIN C PADA KESEHATAN TERNAK RUMINANSIA
}

\author{
(Benefits of Vitamin C Supplementation on Ruminants Health)
}

\author{
Yanuartono ${ }^{1}$, Alfarisa Nururrozi ${ }^{1}$, Indarjulianto Soedarmanto ${ }^{1 *}$, dan Dhasia Ramandani ${ }^{2}$ \\ ${ }^{1}$ Departemen Ilmu Penyakit Dalam, Fakultas Kedokteran Hewan Universitas Gadjah Mada. \\ Jl. Fauna No.2, Karangmalang, Depok, Sleman. 55281 Yogyakarta \\ ${ }^{2}$ Departemen Teknologi Hayati dan Veteriner, Sekolah Vokasi, Universitas Gadjah Mada \\ Jl. Yacaranda, Sekip Unit 1, Caturtunggal, Depok, Sleman \\ Email : indarjulianto@ugm.ac.id
}

\begin{abstract}
Vitamin $C$ is an important water-soluble vitamin that is needed by every living thing. Domestic animals, including ruminants were capable of synthesizing ascorbic acid, primarily in the liver, therefore, vitamin $C$ is not considered to be an essential nutrient for healthy ruminants. Nevertheless, in ruminants, vitamin $\mathrm{C}$ is important in biochemical reactions involving collagen cross-linking, hydroxylation of proline and lysine, and steroid and bile acid synthesis. However, in fact, dietary vitamin $C$ is extensively degraded in the rumen. Although ruminants are able to synthesize vitamin $C$, but when ruminants experience stress and suffer from various diseases, vitamin $C$ supplementation from outside is still needed to restore their health condition. Therefore, vitamin C supplements still have great benefits for optimizing their health conditions. This review discusses the effects of vitamin $\mathrm{C}$ and its supplementation on the health of ruminants.
\end{abstract}

Key words: Vitamin C, ruminants, stress, diseases, supplementation

\begin{abstract}
ABSTRAK
Vitamin C adalah vitamin larut air yang penting dan dibutuhkan oleh setiap makhluk hidup. Hewan peliharaan, termasuk ruminansia mampu mensintesis asam askorbat terutama di hati, oleh karena itu, vitamin $C$ kurang dianggap sebagai nutrisi penting untuk ruminansia sehat. Namun demikian, pada ruminansia, vitamin $C$ penting dalam reaksi biokimiawi yang melibatkan ikatan silang kolagen, hidroksilasi prolin dan lisin, serta sintesis steroid dan asam empedu. Namun, pada kenyataannya, vitamin $C$ dalam pakan secara luas terdegradasi dalam rumen. Meskipun ruminansia mampu mensintesis vitamin $C$, namun saat ruminansia mengalami stress dan menderita berbagai macam penyakit suplementasi vitamin $C$ dari luar tetap dibutuhkan untuk mengembalikan kondisi kesehatannya. Oleh karena itu, suplemen vitamin $C$ tetap memiliki manfaat yang besar guna mengoptimalkan kondisi kesehatannya. Ulasan ini membahas efek vitamin C dan suplementasinya pada kesehatan ruminansia.
\end{abstract}

Kata kunci : Vitamin C, ruminansia, stress, penyakit, suplementasi

\section{PENDAHULUAN}

Pakan merupakan salah satu faktor yang penting dan sangat menentukan dalam pemeliharaan ternak ruminansia. Pakan dengan kualitas maupun kuantitas yang rendah akan menyebabkan penurunan produktivitas ternak (Prabowo et al., 2017; Sohrah and Baba, 2019). Salah satu unsur dalam pakan yang memiliki peran penting adalah vitamin, baik larut air seperti vitamin $B$ dan $C$ maupun vitamin larut lemak seperti A,D,E dan K. Vitamin C (asam askorbat) adalah vitamin larut air yang berperan penting dalam kesehatan makhluk hidup.
Nama kimia vitamin $\mathrm{C}$ atau asam askorbat berdasarkan nomenklatur International Union of Pure and Applied Chemistry (IUPAC) adalah 2-oxo-L-threo-hexono-1,4- lactone-2,3-enediol atau (R)-3,4-dihydroxy-5-((S)-1,2-dihydroxyethyl furan2(5H)-one (IUPAC, 2009). Vitamin C pertama kali diidentifikasi pada awal abad 20 dalam upaya menangani kejadian skorbut atau scuroy (Carpenter, 1986; Schlueter and Johnston, 2010). Hampir semua mamalia mampu memproduksi vitamin C kecuali manusia dan marmot (Horning, 1975). Menurut Combs (2008) vitamin C dapat disintesis dari glukosa di liver oleh ruminansia, babi, kuda, anjing, dan kucing. 
Basu and Schorah (1982) berpendapat bahwa hewan mamalia memiliki kemampuan untuk mensintesis asam L-askorbat melalui jalur asam glukuronat di hati. Sedangkan pada reptil dan burung sintesis asam L-askorbat melalui ginjal dengan memanfaatkan D-glukosa atau D-galaktosa. Meskipun memiliki peran penting pada kesehatan makhluk hidup, namun vitamin $\mathrm{C}$ memiliki beberapa kelemahan yaitu stabilitas rendah serta mudah rusak selama pemrosesan maupun penyimpanan (Leskova et al., 2006; ElIshaq and Obirinakem, 2015). Menurut Lopez et al, (1967) dan Padilla et al. (2007) laju kerusakan semakin meningkat karena pengaruh dari logam serta kerja enzim tertentu.

Menurut Itze (1984) ruminansia muda atau pedet umur 3-4 minggu masih membutuhkan pasokan vitamin $C$ dari luar terutama melalui kolostrum dan susu. Pada ruminansia dewasa, asupan vitamin $C$ dari pakan hampir seluruhnya akan didegradasi oleh mikroorganisme rumen sehingga kebutuhan sapi dewasa sangat tergantung dari sintesis endogen (Nockels, 1988). Oleh sebab itu, semua ruminansia memiliki kapasitas endogen yang besar untuk sintesis asam L-askorbat. Namun demikian, meskipun ruminansia mampu mensintesis vitamin $C$ dari D-glukosa atau D-galaktosa, beberapa laporan penelitian menunjukkan terjadinya penurunan konsentrasi dalam jaringan selama menderita berbagai macam penyakit serta stress (Sahinduran and Albay, 2004 ; Padilla et al., 2006; Amir et al., 2017). Laporan penelitian tersebut mengindikasikan bahwa suplementasi vitamin C masih diperlukan dalam kondisi tertentu terutama guna pemeliharaan kesehatan dan reproduksi.

Suplementasi vitamin C telah banyak dilakukan para peneliti untuk pemeliharaaan kesehatan pedet (MacLeod et al., 2003), kambing (Hidiroglou et al., 1997), sapi potong (Padilla et al., 2007) dan sapi perah (Chaiyotwittayakun et al., 2002). Sedangkan penelitian suplementasi vitamin $C$ untuk kesehatan reproduksi juga telah dilakukan oleh para peneliti seperti Daykin (1960), Naresh et al. (2002) dan Ranjan et al. (2012). Namun, penelitian yang lebih luas serta mendalam masih banyak diperlukan untuk mengeksplorasi kebutuhan dan efek suplementasi vitamin C pada ternak ruminansia, baik pada pedet maupun dewasa. Tulisan ini mencoba untuk mengulas secara sederhana pengaruh vitamin $C$ pada kesehatan ruminansia yang sampai saat ini jarang diperhatikan oleh para praktisi kesehatan hewan di lapangan.

\section{Struktur, sifat kimia dan fungsi vitamin C}

Nama kimia vitamin $C$ atau asam askorbat berdasarkan nomenklatur International Union of Pure and Applied Chemistry (IUPAC) adalah 2-oxoL-threo-hexono-1,4- lactone-2,3-enediol or (R)-3,4dihydroxy-5-((S)-1,2-dihydroxyethyl furan-2(5H)one (IUPAC, 2009). Molekul vitamin $C$ terbentuk dari atom enam karbon asimetris $\left(\mathrm{C}_{6} \mathrm{H}_{8} \mathrm{O}_{6}\right)$ yang secara struktural terkait dengan glukosa (Varvara et al., 2016). Vitamin C berbentuk kristal putih yang mudah larut dalam air, meskipun dalam keadaan kering vitamin C cukup stabil, namun demikian dalam kondisi terlarut vitamin C mudah rusak karena kontak dengan udara terutama bila terkena panas (Washko et al., 1993; Pires et al., 2008). Menurut Tsao and Young (1996) vitamin C tidak stabil dalam larutan alkali, tetapi cukup stabil dalam larutan asam. Papoutsis et al. (2016) menambahkan bahwa vitamin $C$ mudah larut dalam air, tidak mudah larut dalam etanol, tidak larut dalam kloroform, eter dan benzene. Vitamin C masuk dalam kelompok antioksidan karena sangat mudah teroksidasi oleh panas, cahaya, dan logam (Matei et al., 2008; Mercali et al., 2012) sehingga wajib disimpan dalam wadah tertutup rapat serta tidak tembus cahaya (Zee et al., 1991; Stešková et al., 2006). Padayatty et al. (2003) menambahkan bahwa vitamin C memiliki kemampuan menangkap radikal bebas sehingga menghambat proses oksidasi. Menurut Naidu (2003) vitamin C di alam terdapat dalam dua bentuk, yaitu L-asam askorbat (bentuk tereduksi) dan L-asam dehidro askorbat (bentuk teroksidasi).

Vitamin C memiliki sejumlah aktivitas yang memiliki kontribusi terhadap modulasi efek kekebalan tubuh (Bendich, 1993; Carr and Maggini, 2017). Vitamin C adalah antioksidan yang sangat efektif, karena kemampuannya dalam menyumbangkan elektron, sehingga melindungi biomolekul penting seperti protein, lipid, karbohidrat, dan asam nukleat dari kerusakan oleh oksidan yang dihasilkan selama metabolisme sel normal dan melalui paparan racun ataupun polutan (Webb and Villamor, 2007; Carr and Maggini, 2017). Menurut Combs (2008) fungsi lain dari vitamin C adalah sebagai kofaktor oksigenase yang terlibat dalam sintesis kolagen, katekolamin, dan karnitin, dan dalam metabolisme xenobiotik, kolesterol, serta tirosin. Selain itu, vitamin $C$ berfungsi sebagai katalis dalam reaksi-reaksi kimia yang terjadi di dalam tubuh hewan, sehingga apabila katalis ini tidak tercukupi seperti pada kondisi defisiensi, maka fungsi normal tubuh akan terganggu 
(Fahimi et al., 2016). Cook and Reddy (2001) menambahkan bahwa salah satu peran vitamin $C$ yang utama adalah membantu penyerapan zat besi. Selain itu, vitamin $C$ juga berfungsi untuk menjaga daya tahan tubuh serta memulihkan kondisi tubuh akibat adanya reaksi oksidasi dari berbagai senyawa oksidan berbahaya bagi kesehatan tubuh (Padayatty et al., 2003). Dari berbagai macam fungsi vitamin $C$ tersebut, saat ini yang tetap menarik para peneliti adalah kemampuannya sebagai antioksidan. Peran sebagai antioksidan sangat terkait dengan fungsi dan integritas berbagai sel tubuh, fungsi detoksifikasi, fungsi normal kelenjar adrenal, paru-paru, otak, mata dan sistem kekebalan tubuh (Zulkifli et al., 2000; Hediger, 2002; McDowell, 2002; Nayyar and Jindal, 2010; Pogge, 2013). Dengan demikian fungsi antioksidan tersebut jika dapat dioptimalkan penggunaannya pada ternak ruminansia akan dapat meningkatkan penampilan ternak secara keseluruhan.

\section{Sumber dan peran vitamin C}

Vitamin $C$ banyak berasal dari sumber alami seperti buah-buahan segar dan sayuran (Haytowitz, 1995; Nkafamiya et al., 2010). Selain sumber diatas, vitamin $\mathrm{C}$ juga ditemukan dalam hati dan ginjal, serta daging, meskipun dalam jumlah yang terbatas (Fediuk, 2000; Fediuk et al., 2002). Sumber utama vitamin C untuk ruminansia sangat tergantung pada sintesis endogen karena vitamin $C$ asal pakan hampir seluruhnya dirusak oleh mikroorganisme rumen (Nockels, 1988). Semua ruminansia memiliki kapasitas untuk sintesis vitamin C endogen (Nwunuji et al., 2014), namun demikian, pedet baru lahir sampai berumur 2 - 3 bulan belum mampu mensintesis vitamin C sehingga semua kebutuhannya tergantung dari pasokan kolostrum dan susu (Hemingway, 1991; Moallemzadeh et al., 2015). Hasil penelitian tersebut mendukung penelitian sebelumnya oleh Wegger and Moustgaard, (1982) yang menyatakan bahwa pedet sampai umur 4 bulan belum mampu menghasilkan vitamin $C$.

Vitamin $C$ memiliki banyak peran pada makhluk hidup, termasuk ruminansia. Peran pada ruminansia telah banyak ditunjukkan hasil penelitian yang telah banyak dipublikasikan seperti yang ditunjukkan pada contoh penelitian dibawah ini (Duncan et al., 1944; Frei et al., 1989; Combs, 2008; Sivakumar et al., 2010; Rejeb and Najar, 2018). Vitamin C berperan dalam sintesis kolagen, katekolamin (Combs,
2008), karnitin, metabolisme kolesterol, tirosin dan kortikosteroid (Finn and Johns 1980), pembentukan asam empedu (Simon, 1993) dan meningkatkan kekebalan tubuh (Wolf, 1993; MacLeod et al., 2003). Vitamin C juga berperan dalammeningkatkan penyerapan mineral Fe dari pakan dan mobilisasi serta distribusi ke seluruh tubuh (Carr and Maggini, 2017). Lebih lanjut, menurut Olivares et al. (1997), vitamin C mampu meningkatkan penyerapan zat besi non-heme dari pakan dan berperan dalam menurunkan konsentrasi zat besi pada kondisi $\mathrm{pH}$ asam di lambung. Penelitian tentang manfaat vitamin C pada ruminansia telah banyak dilakukan terutama untuk memenuhi kebutuhan pada saat sintesis endogen tidak tercukupi akibat dari berbagai macam kondisi seperti penyakit (Grosso et al., 2013), stress transportasi (Ayo et al., 2006), stress panas (Sivakumar et al., 2010) dan produksi tinggi pada sapi perah (Rejeb and Najar, 2018).

Peran paling utama dari vitamin $\mathrm{C}$ adalah sebagai antioksidan yang berfungsi melindungi kerusakan sel akibat radikal bebas (Bendich et al., 1986; May et al., 1998; Pehlivan, 2017). Sebagai antioksidan yang kuat, vitamin $\mathrm{C}$ banyak terkandung dalam plasma darah, netrofil dan jaringantubuhlainnya(Washkoetal.,1993).Salah satu peran vitamin $C$ dalam sistem pertahanan tubuh adalah melindungi netrofil dari stress oksidatif yang dipicu oleh radikal bebas (Wolf, 1993). Vitamin C memiliki berbagai macam peran fisiologis yang berperan penting dalam pertahanan tubuh serta dalam batas tertentu mampu memberikan perlindungan dari proses kerusakan oksidatif pada level seluler maupun subseluler. Meskipun ruminansia mampu mensintasis vitamin $C$, namun demikian dari berbagai laporan penelitian menunjukkan bahwa saat ruminansia mengalami stress, menderita berbagai macam penyakit maka tetap dibutuhkan suplementasi vitamin $C$ dari luar untuk mengembalikan kondisi kesehatannya (Matsui, 2012). Saat ini vitamin C telah tersedia secara komersial dalam bentuk kristal murni, bentuk salut (coated), meskipun demikian, bentuk L-ascorbyl-monophosphate merupakan bentuk komersial yang paling stabil digunakan dalam industri pakan ternak (de Rodas et al., 1998; Macleod, et al., 1999; Hidiroglou, 1999).

\section{Dampak defisiensi vitamin C pada ruminansia}

Defisiensi vitamin C dapat dialami oleh ruminansia besar seperti sapi perah 
(Kleczkowski et al., 2005), sapi potong (Padilla et al., 2006), pedet (Seifi et al., 1996) maupun ruminansia kecil seperti domba (Eberhard et al., 1989) dan kambing (Kour et al., 2018) yang dapat mengakibatkan dampak yang buruk bagi kesehatan hewan. Menurut Cummins (1992), salah satu contoh dampak defisiensi vitamin C pada pedet adalah scurvy, penurunan integritas dan kondisi kesehatan mukosa serta hilangnya pertahanan tubuh terhadap berbagai macam penyakit. Scurvy pada pedet ditandai dengan lesi pada rongga mulut dan kulit, kadar vitamin $C$ rendah, rentan terhadap penyakit, nyeri otot dan perdarahan subkutan (Duncan, 1944; Radostits et al., 1994; Sahinduran and Albay, 2004). Penyakit akibat defisiensi vitamin $C$ pada ruminansia tersaji pada Tabel 1 .

Tabel 1 menunjukkan dampak negatif defisiensi vitamin $C$ pada ruminansia dan salah satu dampak yang sering muncul berupa heat stress baik ruminansia besar maupun kecil. Heat stress yang disebabkan oleh defisiensi vitamin $C$ pada ruminansia jarang menjadi perhatian utama karena ruminansia dianggap mampu memproduksi dan mencukupi kebutuhan vitamin $C$ sendiri. Meskipun demikian hasil penelitian menunjukkan bahwa pengaruh heat stress pada penampilan ruminansia sangatlah besar karena mengakibatkan kesulitan dalam prosespembuanganpanastubuhyangberlebihan ke lingkungan. Proses pembuangan panas tubuh yang terganggu akan mengakibatkan penurunan asupan pakan dan laktasi, gangguan pertumbuhan, kebuntingan serta konsepsi (AlAzzawi et al., 2017; Sarangi, 2018). Menurut Kleczkowski et al. (2005) defisiensi vitamin C pada sapi perah dapat mengakibatkan mastitis. Weiss et al. (2004) menambahkan bahwa tingkat keparahan mastitis berbanding lurus dengan penurunan konsentrasi vitamin C dalam plasma dan susu. Defisiensi vitamin $\mathrm{C}$ juga mengakibatkan gangguan reproduksi ruminansia seperti infertilitas (Izquierdo et al., 2019), pengecilan ukuran folikel (Khan and Das 2011) dan gangguan siklus estrus (Phillips et al., 1941; Luck and Zhao, 1993).

Menurut Nockels (1988) kemampuan ruminansia dewasa dalam mensintesis vitamin C merupakan sebuah kelemahan karena membuat minimnya data kebutuhan vitamin C yang tersedia sehingga kebutuhan didasarkan atas asumsi bahwa sintesis endogen cukup untuk memenuhi kebutuhan ruminansia dewasa. Namun demikian jika melihat dampak yang ditimbulkan akibat defisiensi vitamin C maka pada akhirnya tetap dibutuhkan

Tabel 1. Dampak defisiensi vitamin C pada ruminansia

\begin{tabular}{lll}
\hline Hewan & Dampak & Pustaka \\
\hline Sapi & $\begin{array}{l}\text { Scurvy dan penurunan } \\
\text { berat badan, kematian }\end{array}$ & Duncan, 1944 \\
Pedet & Hemoragi subkutan & Pribyl, 1963 \\
Pedet & Pneumonia & Jagos et al., 1977 \\
Pedet & Scurvy & Matsui, 2012 \\
Pedet & Stres & Cummins and Brunner 1991 \\
Pedet & Dermatosis & Al-Autaish, 2019 \\
Kambing & Mastitis subklinis & Gupta et al., 1999 \\
Sapi & Retensi plasenta & Kankofer, 2001 \\
Pedet & Diare & Sahinduran and Albay 2004 \\
Sapi & Mastitis & Kleczkowski et al., 2005 \\
Kerbau & Heat stress & Kumar et al., 2011 \\
Domba & Heat stress & Babe, 2011 \\
Sapi & Dermatosis & Anoushepour et al., 2013 \\
Kerbau & Heat stress & Ganaie et al., 2013 \\
Kambing & Stres transportasi & Biobaku et al., 2017 \\
Domba & Heat stress & Al-Azzawi et al., 2017 \\
Kambing & Heat stress & Biobaku et al., 2018 \\
\hline
\end{tabular}


suplementasi vitamin C untuk memperbaiki dan meningkatkan kesehatan ternak. Oleh sebab itu masih banyak diperlukan penelitian yang lebih mendalam untuk mengeksplorasi kebutuhan dan efek suplementasi vitamin C pada ternak.

\section{Suplementasi vitamin C}

Suplemen vitamin C untuk ruminansia dapat diperoleh dalam berbagai bentuk seperti serbuk, dilapis dengan ethyl cellulose atau dicampur dengan pakan (Abd-El-Rahman et al., 2015). Hidiroglou (1999) dalam penelitian suplementasi vitamin C menggunakan bentuk serbuk yang dilapis dengan ethyl cellulose dan bentuk serbuk yang diberikan melalui fistula abomasum. Pelapis ethyl cellulose digunakan untuk melindungi vitamin $C$ dari degradasi oleh mikrofolora dalam rumen. Metode suplementasi yang lain adalah melalui injeksi subkutan ataupun intramuskular, namun demikian metode tersebut memiliki kelemahan karena dapat menyebabkan iritasi dan peradangan. Metode injeksi subkutan ataupun intramuskular akan lebih aman jika menggunakan bentuk natrium askorbat yang bersifat kurang asam (Ranjan et al., 2012). Dampak suplementasi vitamin $C$ terhadap kesehatan ruminansia tersaji pada Tabel 2.

Tabel 2 menunjukan berbagai manfaat suplementasi vitamin C pada ruminansia. Suplementasi vitamin $C$ tersebut dapat melalui oral maupun injeksi. Suplementasi oral lebih dianjurkan pada pedet karena rumen belum berkembang sehingga tidak banyak terjadi kerusakan vitamin C akibat degradasi oleh mikroorganisme dalam rumen. Selain hal tersebut diatas, pedet yang baru lahir juga belum mampu mensintesis vitamin $C$ sehingga dianjurkan untuk memberikan suplementasi vitamin $C$ guna mencegah munculnya penyakit seperti scurvy, stress, penurunan berat badan, penurunan kekebalan tubuh dan bahkan kematian. Tabel 2 juga menunjukkan bahwa suplementasi vitamin $C$ banyak memberikan manfaat seperti pengobatan diare, menurunkan tingkat heat stress, stress akibat transportasi, peningkatan respon imun dan mempercepat kesembuhan mastitis. Menurut McDowell (2000) suplementasi vitamin C dengan dosis 1 hingga $2 \mathrm{~g}$ per hari sangatlah bermanfaat dalam mengurangi mengobati kondisi tersebut diatas. Cummins and Brunner (1989) menambahkan bahwa kolostrum memiliki kandungan vitamin $C$ yang tinggi sehingga sangat bermanfaat bagi pedet yang baru lahir dan dapat menurunkan kejadian peritonitis, pneumonia, enteritis bahkan kematian pada pedet.

Tabel 1. Manfaat suplementasi vitamin C untuk meningkatkan kesehatan dan produksi pada ruminansia

\begin{tabular}{|c|c|c|c|}
\hline Hewan & Suplementasi & Perubahan & Pustaka \\
\hline Pedet & $\begin{array}{l}\text { Vitamin C oral } 1000 \mathrm{mg} / 2 \\
\text { kali/hari }\end{array}$ & Pengobatan diare & Seifi et al., 1996 \\
\hline Sapi & $\begin{array}{l}\text { Vitamin C } 25 \mathrm{mg} / \mathrm{kg} \mathrm{BB} \text {, } \\
\text { subkutan }\end{array}$ & $\begin{array}{l}\text { Mempercepat kesembuhan } \\
\text { mastitis klinis }\end{array}$ & Naresh et al., 2002 \\
\hline Pedet & $\begin{array}{l}\text { Vitamin C oral } 1000 \mathrm{mg} / 3 \\
\text { kali/hari }\end{array}$ & Pengobatan enteritis & $\begin{array}{l}\text { Sahinduran and Albay, } \\
2004\end{array}$ \\
\hline Kambing & $\begin{array}{l}\text { Vitamin C oral } 100 \mathrm{mg} / \\
\mathrm{kg} \mathrm{BB}\end{array}$ & $\begin{array}{l}\text { Menurunkan eksitabilitas } \\
\text { saat transportasi }\end{array}$ & Ayo et al., 2006 \\
\hline Rusa & $\begin{array}{l}\text { Vitamin C oral } 75 \mathrm{mg} / \mathrm{kg} \\
\text { BB }\end{array}$ & Peningkatan kualitas susu & $\begin{array}{l}\text { Abd-El-Rahman et al., } \\
2015\end{array}$ \\
\hline Sapi & Injeksi vitamin C $3 g$ & Pengobatan dermatosis & $\begin{array}{l}\text { Anoushepour et al., } \\
2013\end{array}$ \\
\hline Kerbau & vitamin C oral $10 \mathrm{~g} /$ hari & $\begin{array}{l}\text { Peningkatan status keke- } \\
\text { balan }\end{array}$ & Ganaie et al., 2013 \\
\hline Domba & vitamin $C$ oral $2,5 \mathrm{~g} /$ hari & Mencegah heat stress & $\begin{array}{l}\text { Abd-Allah and } \\
\text { Zanouny, } 2014\end{array}$ \\
\hline Sapi & $\begin{array}{l}\text { Vitamin C oral } 20 \mathrm{~g} / 100 \mathrm{~kg} \\
\text { BB }\end{array}$ & Peningkatan respon imun & Rejeb et al., 2016 \\
\hline Kambing & $\begin{array}{l}\text { Vitamin C oral } 180 \mathrm{mg} / \mathrm{kg} \\
\mathrm{BB} / \text { hari }\end{array}$ & $\begin{array}{l}\text { Menurunkan dampak } \\
\text { stress transportasi }\end{array}$ & Gupta et al., 2018 \\
\hline
\end{tabular}




\section{KESIMPULAN}

Vitamin C memiliki banyak peran pada ruminansia. Meskipun dapat disintesis oleh ruminansia, namun dalam kondisi tertentu suplementasi vitamin $\mathrm{C}$ masih dibutuhkan oleh ruminansia terutama oleh pedet yang belum mampu mensintesis vitamin C. Bagi ruminansia, suplementasi vitamin C masih dibutuhkan dalam kondisi tertentu seperti kondisi stress, memperbaiki kondisi tubuh pasca kesembuhan dari penyakit serta peningkatan respon imun.

\section{DAFTAR PUSTAKA}

Abd-Allah, M., and A. I. Zanouny. 2014. Ameliorative effect of ascorbic acid administration and chilled drinking water on ram lambs exposed to heat stress during summer season. Egyptian Journal of Sheep and Goat Sciences, 9 (3): 17- 28.

Abd-El-Rahman, H.M.A., M. A. Ibrahim, R. M. A. Dohreig, and H. A. E. Asfour. 2015. The relation between oxidative status, milk quality and conception rate in dairy goats supplemented with vitamin C. Assiut Vet. Med. J., 61(145): 257-269.

Al-Autaish, H. H. N. 2019. The influence of vitamin $\mathrm{C}$ deficiency on dermatosis in neonatal dairy calves. Kufa Journal For Veterinary Medical Sciences, 10(1): 47-55.

Al-Azzawi, S. H., R. I. Khalil, and Z. I. Mohammed. 2017. Effect of Vitamin $C$ administration on heat tolerance of local and Turkish Awassi sheep in Diyala Province of Iraq. Bas. J. Vet. Res., 16(1): 288-297.

Amir, A., B. P. Purwanto, and I. G. Permana. 2017. Thermoregulation response of dairy cows on different energy content. JITP, 5(2): 72-79.

Anoushepour, A., M. Sakha, and P. Mortazavi. 2013. A clinical case: vitamin C-responsive dermatosis in a Holstein native cross bull calf. Turk. J. Vet. Anim. Sci., 37(2): 234-237.

Ayo, J. O., N. S. Minka, and M. Mamman. 2006. Excitability scores of goats administered ascorbic acid and transported during hot-dry conditions. J. Vet. Sci., 7(2): 127-131.

Babe, A. A. 2011. Effect of vitamin Con haematology and serum biochemistry in heat-stressed sheep. Roavs., 1(11): 731-733.

Basu, T. K., and C. J. Schorah. 1982. Vitamin C in health and disease. AVIPublishing Company, Westport.

Bendich, A. 1993. Symposium: antioxidants, immune response, and animal function physiological role of antioxidants in the immune system. J. Dairy Sci., 76 (9): 27892794.

Bendich, A., L. J. Machlin, O. Scandurra, G. W. Burton, and D. D. M. Wayner. 1986. The antioxidant role of vitamin C. Advances in Free Radical Biology and Medicine, 2(2): 419444.

Biobaku, K. T., T. O. Omobowale, A. O. Akeem, A. Aremu, N. Okwelum, and A. S. Adah. 2018. Use of goat interleukin-6, cortisol, and some biomarkers to evaluate clinical suitability of two routes of ascorbic acid administration in transportation stress. Vet. World, 11(5): 674-680.

Biobaku, K.T., B.M. Agaie, and A. Aremu. 2017. Evaluating stress amelioration of oral vitamin $C$ in Bucks Exposed to long term road transportation and stocking. Bangl. J. Vet. Med. 15 (1): 33-38

Carpenter, K. J. 1986. The History of Scurvy and Vitamin C. Cambridge University Press, Cambridge, UK.

Carr, A. C., and S. Maggini. 2017. Vitamin C and immune function. Nutrients, 9(11): 1211.

Chaiyotwittayakun, A., R. J. Erskine, P. C. Bartlett, T. H. Herd, P. M. Sears, and R. J. Harmont. 2002. Theeffect of ascorbic acid and L-histidine therapy on acute mammary inflammation in dairy cattle. J. Dairy Sci., 85(1): 60-67.

Combs, G. F. 2008. Vitamin C. In: The vitamins: Fundamental Aspects in Nutrition and Health. Combs G F. (editor). Third Edition. Academic Press, San Diego, USA. pp. 235-263.

Cook, J. D., and M. B. Reddy. 2001. Effect of ascorbic acid intake on nonheme-iron absorption from a complete diet. American Journal of Clinical Nutrition. 73(1): 93-98.

Cummins, K. A., and C. J. Brunner 1991. Effect of calf housing on plasma ascorbate and endocrine and immune function. J. Dairy Sci., 74(5): 1582-1588.

Cummins, K. A. 1992. Ascorbate in cattle: A review. Prof. Anim. Sci. 8(1): 22-29.

Daykin, P. W. 1960. Veterinary Applied Pharmacology and Therapeutics. Bailliere Tindall and Cassell, London. pp. 619-621.

de Rodas, B. Z., C. V. Maxwell, M. E. Davis, S. Mandali, E. Broekman, and B. J.Stoecker. 1998. L-ascorbyl-2-polyphosphate as a vitamin C source for segregated and conventionally weaned pigs. J. Anim. Sci., 76(6): 1636-1643.

Duncan, C. W., C. F. Huffman, R. Mitchell, Jr., and 
J. T. Reid. 1944. Symptom of scurvy observed in a herd of cattle. J. Dairy Sci., 24: 636

Duncan, C. W. 1944. Studies on the influence of ascorbic acid in calves with scurvy. J. Dairy Sci., 27: 636.

Eberhard, K., P. Kronhusen, B. Harry, and M. D. Demopoulos. 1989. Formula for life, William Marrow and Co., New York. pp: 96-102.

El-Ishaq, A., and S. Obirinakem. 2015. Effect of temperature and storage on vitamin $\mathrm{C}$ content in fruits juice. Intl. J. Chem. Biomol. Sci., 1(2): $17-21$

Fahimi, N., A. R. Sardarian, and M. Kazemnejadi. 2016. Vitamin C as a green and efficient catalyst in synthesis of quinoxaline derivatives at room temperature. Iranian Journal of Catalysis, 6(2): 161-166.

Fediuk, K. 2000. Vitamin C in the Inuit diet: past and present. MA Thesis. School of Dietetics and Human Nutrition, McGill University, Montreal, Canada.

Fediuk K., N. Hidiroglou, R. Madère, and H. V. Kuhnlein. 2002. Vitamin C in Inuit Traditional Food and Women's Diets. J. Food Comp. Anal., 15(3): 221-235.

Finn, F. M., and P. A. Johns. 1980. Ascorbic acid transport by isolated bovine adrenal cortical cells. Endocrinology, 106(3): 811-817.

Frei, B., L. England, and B. N. Ames. 1989. Ascorbate as an outstanding antioxidant in human blood plasma. Proc. Natl. Acad. Sci. USA. 86: 6377-6381.

Ganaie, A. H., O. K. Hooda, S. V. Singh, Ashutosh, and R. C. Upadhyay. 2013. Effect of vitamin C supplementation on immune status and oxidative stress in pregnant Murrah buffaloes during thermal stress. Indian Journal of Animal Sciences, 83(6): 649-655.

Grosso, G., R. Bei, A. Mistretta, S. Marventano, G. Calabrese, L. Masuelli, M. G. Giganti, A. Modesti, F. Galvano, and D. Gazzolo. 2013. Effects of Vitamin C on health: a review of evidence. Front Biosci., 18(3): 1017-1029.

Gupta, D., M. Ashutosh, G. Kashyap, M. Punetha, Ashutosh, B. Patel, I. Para, and M. Ahirwar. 2018. Seasonal effect of vitamin C, electrolyte and jaggery supplementation on body weight of goats transported at different flocking density. Int. J. Curr. Microbiol. App. Sci., 7(4): 1761-1768.

Gupta, V. K., A. Kumar, and S. D. Sharma. 1999. Plasma ascorbic acid in healthy and subclinical mastitic goats. Indian J. Vet. Med., 19: 83-85.
Haytowitz, D. B. 1995. Information from USDA's Nutrient Data Bank. J. Nutr., 125: 1952-1955.

Hediger, M. A. 2002. New view at vitamin C. Nat. Med., 8(5): 445-446.

Hemingway, D. C. 1991. Vitamin C in the prevention of neonatal calf diarrhea. Can. Vet. J., 32(2): 184.

Hidiroglou, M. 1999. Technical Note: Forms and Route of Vitamin C Supplementation for Cows. J. Dairy Sci., 82(8): 1831-1833.

Hidiroglou, M., T. R. Batra, and X. Zhao. 1997. Comparison of vitamin $C$ bioavailability after multiple or single oral dosing of different formulations in sheep. Reprod. Nutr. Dev., 37(4): 443-448.

Horning, D. 1975. Metabolism of ascorbic acid. World Rev. Nutr. Diet., 23:225-258.

Itze, L. 1984. Ascorbic acid metabolism in ruminants. in Ascorbic Acid in Domestic Animals. I. Wegger, ed. Royal Danish Agric. Soc., Copenhagen, Denmark. pp 120-130

IUPAC. 2009. Systematic IUPAC Name in Vitamin C.

Izquierdo, A. C., J. E. G. Liera, A. E. V. Mancera, R. H. Crispín, A. E. I. Reyes, M. L. J. Mosqueda, A. G. Vázquez, J. O Pérez, B. E. R. Denis, and R. S. Sánchez. 2019. Causes of Infertility in Cows. Arch Animal Husb. and Dairy Sci., 1(3): 1-2.

Jagos, P., J. Bouda, and R. Dvorrak. 1977. Ascorbic acid levels in the bronchopneumonia of calves. Vet. Med., 22(3): 133-136.

Kankofer, M. 2001. Non-enzymatic antioxidative defense mechanisms against reactive oxygen species in bovine-retained and not-retained placenta: vitamin C and glutathione. Reprod. Domest. Anim., 36(3-4): 203-206.

Khan, F. A., and G. K. Das. 2011. Follicular fluid nitric oxide and ascorbic acid concentrations in relation to follicular size, functional status and stage of estrous cycle in buffalo. Anim. Reprod. Sci., 125 (1-4): 62-68.

Kleczkowski, M., W. Kluciński, A. Shaktur, and J. Sikora. 2005. Concentration of ascorbic acid in the blood of cows with subclinical mastitis. Pol. J. Vet. Sci., 8(2): 121-125.

Kour, S., J. Devi, K. Sarma, D. Chakraborty, R. Zargar, A. W. Ganai, and P. Khajuria. 2018. Effect of Vitamin C on Some Oxidative Stress Parameters in Water Deprived Goats. Journal of Animal Research, 8(2): 251-257.

Kumar, A., G. Singh, B. V. S. Kumar, and S. K. Meur. 2011. Modulation of antioxidant status and lipid peroxidation in erythrocyte 
by dietary supplementation during heat stress in buffaloes. Livest. Sci., 138 (1-3): 299-303.

Leskova, E., J. Kubikova, E. Kovacikova, E. Kosicka, J. Porubska, and K. Holcikova. 2006. Vitamin losses: Retention during heat treatment and continual changes expressed by mathematical models. Journal of Food Composition and Analysis, 19(4): 252-276.

Lopez, A., W. A. Krehl, and E. Good. 1967. Influence of time and temperature on ascorbic acid stability. J. Am. Diet Assoc., 50(4): 308-310

Luck, M. R., and Y. Zhao. 1993. Identification and measurement of collagen in the bovine corpus luteum and its relationship with ascorbic acid and tissue development. J. Reprod. Fertil., 99(2): 647-652.

Macleod, D. D., X. Zhang, L. Ozimeck, and J. J. Kennelly. 1999. Ascorby L-2-polyphosphate as a source of ascorbic acid for dairy cattle. Milchwissenschaft, 54: 123-126.

MacLeod, D., L. Ozimeck, and J. J. Kennelly. 2003. Supplemental vitamin C may enhance immune function in dairy cows. In: Proceedings of Western Canadian Dairy Seminar, http:/ / www.wcds.ca/proc /1996/ wcd96227.htm.

Matei, N., S. Birghila, V. Popescu, S. Dobrinas, A. Soceanu, C. Oprea, and V. Magearu. 2008. Kinetic study of vitamin $C$ degradation from pharmaceutical products. Rom. Journ. Phys., 53(1-2): 343-351.

Matsui, T. 2012. Vitamin Cnutrition in cattle. AsianAustralas J. Anim. Sci., 25(5): 597-605.

May, J. M., Z. C. Qu, and S. Mendiratta. 1998. Protection and recycling of $\alpha$-tocopherol in human erythrocytes by intracellular ascorbic acid. Arch. Biochem. Biophys., 349 (2): 281289.

McDowell, L.R. 2002. Recent advances in minerals and vitamins on nutrition of lactating cows. Pak. J. Nutr., 1(1): 8-19.

Mercali, G. D., D. P. Jaeschke, I. C. Tessaro, and L. D. F. Marczak. 2012. Study of vitamin C degradation in acerola pulp during ohmic and conventional heat treatment. LWT - Food Science and Technology, 47 (1): 91-95.

Moallemzadeh, F., G. Moghaddam, and F. Soltanpour. 2015. Effect of supplemental vitamin $C$ and $E$ on the immune response of newborn calves. J. Agri-Food \& Appl. Sci., 3(3):63-67

Naidu, K. A. 2003. Vitamin C in human health and disease is still a mystery? An overview. Nutr. J., 2(7): 1-10.
Naresh, R., S. K. Dwivedi, D. Swarup, and R. C. Patra. 2002. Evaluation of ascorbic acid treatment in clinical and subclinical mastitis of dairy cows. Asian Austral. J. Anim. Sci., 15(6): 905-911.

Nayyar, S., and R. Jindal. 2010. Review Article Essentiality of antioxidant vitamins for ruminants in relation to stress and reproduction. Iranian Journal of Veterinary Research, 11(1): 1-9

Nkafamiya, I. I., S. A. Oseameahon, U. U. Modibbo, and D. Haggai. 2010. Vitamins and effect of blanching on nutritional and antinutritional values of non-conventional leafy vegetables. African Journal of Food Science, 4(6): 335341.

Nockels, C. F. 1988. The role of vitamin in modulating disease resistance. Veterinary Clinics of North America: Food Animal Practice, 4(3): 531-532.

Nwunuji,, T. P., O. O. Mayowa, S. M. Yusoff, S. K. Bejo, S. Salisi, and E. A. W. Mohd. 2014. The ameliorative effect of ascorbic acid on the oxidative status, live weight and recovery rate in road transport stressed goats in a hot humid tropical environment. Anim. Sci. J., 85: 611-616.

Olivares, M., F. Pizzaro, O. Pineda, J.J. Name, E. Hertrampf, and T. Walter. 1997. Milk inhibits and ascorbic acid favors ferrous bis-glycine chelate bioavailability in humans. J. Nutr., 127(7): 1407-1411.

Padayatty, S. J., A. Katz, Y. Wang, P. Eck, O. Kwon, J. H. Lee, S. Chen, C. Corpe, A. Dutta, S. K. Dutta, and M. Levine. 2003. Vitamin C as an Antioxidant: Evaluation of Its Role in Disease Prevention. J. Am. Coll. Nutr., 22(1): 18-35.

Padilla, L., T. Matsui, Y. Kamiya, M. Kamiya, M. Tanaka, and H. Yano. 2006. Heat stress decreases plasma vitamin $\mathrm{C}$ concentration in lactating cows. Livest. Sci., 101(1): 300-304.

Padilla, L., T. Matsui, S. Ikeda, M. Kitagawa, and H. Yano. 2007. The effect of vitamin C supplementation on plasma concentration and urinary excretion of vitamin $C$ in cattle. J. Anim. Sci., 85(12): 3367-3370.

Papoutsis, K., P. Pristijono, J. B. Golding, C. E. Stathopoulos, C. J. Scarlett, M. C. Bowyer, and Q. Vuong. 2016. Impact of different solvents on the recovery of bioactive compounds and antioxidant properties from lemon (Citrus limon L.) pomace waste. Food science and biotechnology, 25(4): 971-977.

Pehlivan, F. E. 2017. Vitamin C: An Antioxidant Agent. Chapter from the book Vitamin C. pp. 
23-35.

Phillips, P. H., H. A. Lardy, P. D. Boyer, and G. M. Werner. 1941. The relationship of ascorbic acid to reproduction in the cow. J. Dairy Sci., 24(2): 153-158.

Pires, R. F., and M. R. Franco, Jr. 2008. Solubility of benzoic acid in aqueous solutions containing ethanol or N-propanol. J. Chem. Eng. Data., 53(11): 2704-2706.

Pogge, D. J. 2013. The effect of supplemental vitamin $\mathrm{C}$ on performance, antioxidant capacity, carcass characteristics, and meat quality of steers fed high sulfur finishing diets. Graduate Theses and Dissertations. 13575

Prabowo, M. D., P. Sambodho, D. W. Harjanti, and S. A. B. Santosa. 2017. Pengaruh penambahan bakingsodadalampakanterhadapkandungan serum glutamat piruvat transaminase dan serum glutamat oksaloasetat transaminase sapi perah laktasi. JITP, 5(3): 128-132.

Pribyl, E. 1963. Diseases of young cattle. SZn, Praha. p. 230.

Radostits, O. M., D. C. Blood, and C. C. Gay. 1994. Veterinary Medicine: a Textbook of Diseases of Cattle, Sheep, Pigs, Goats and Horses. ELBS with Bailliere Tindall, London.

Ranjan, R., A. Ranjan, G. S. Dhaliwal, and R. C. Patra. 2012. L-Ascorbic acid (vitamin C) supplementation to optimize health and reproduction in cattle. Veterinary Quarterly, 32(3-4): 145-150

Rejeb, M. and T. Najar. 2018. A survey on the effect of plasma vitamin $C$ on white blood constituents under heat stress condition for dairy cows. Journal of Animal and Plant Sciences, 38(1): 6206-6216.

Rejeb, M., R. Sadraoui, and T. Najar. 2016. Role of Vitamin C on Immune Function Under Heat Stress Condition in Dairy Cows. Asian Journal of Animal and Veterinary Advances, 11(11): 717-724.

Sahinduran, S. and M. K. Albay. 2004.Supplemental ascorbic acid and prevention of neonatal calf diarrhoea. Acta Vet. Brno, 73(2): 221-224.

Sarangi, S. 2018. Adaptability of goats to heat stress: A review. The Pharma Innovation Journal. 7(4): 1114-1126

Schlueter, A. K. and C. S. Johnston. 2010. Vitamin C: Overview and Update. Journal of EvidenceBased Complementary and Alternative Medicine, 16(1): 49-57.

Seifi, H.A., M. R. Dezfuly and M. Bolurchi. 1996. The effectiveness of ascorbic acid in the prevention of calf neonatal diarrhoea. J. Vet. Med. Series B., 43(3): 189-191.

Simon, J. A. 1993. Ascorbic acid and cholesterol gallstones. Medical Hypotheses, 40(2): 81-84.

Sivakumar, A. V. N., G. Singh, and V. P. Varshney. 2010. Antioxidants supplementation on acid base balance during heat stress in goats. Asian Austral. J. Anim. Sci., 23(11): 1462-1468.

Stešková, A., M. Morochovičová, and E. Lešková. 2006. Vitamin C degradation during storage of fortified foods. Journal of Food and Nutrition Research, 45(2): 55-61.

Sohrah, S., and S. Baba. 2019. Factors that Influence the Farmers Perception on the Utilization of Rice Straw as Feed in Bantimurung SubDistrict. JITV, 7(2): 1-7.

Tsao, C. S., and M. A. Young. 1996. Stabilized ascorbic acid solution. Med. Sci. Res., 24: 473-475

Varvara, M., G. Bozzo, C. Disanto, C. N. Pagliarone, and G. V. Celano. 2016. The use of the ascorbic acid as food additive and technical-legal issues. Italian Journal of Food Safety, 5(1): $1-9$.

Washko, P. W., Y. Wang, and M. Levine. 1993. Ascorbic acid recycling in human neutrophils. J. Biol. Chem., 268(21): 15531-15535

Webb, A. L., and E. Villamor. 2007. Update: Effects of antioxidant and non-antioxidant vitamin supplementation on immune function. Nutr. Rev., 65(5): 181-217.

Wegger, I., and J. Moustgaard. 1982. Age variations in plasma ascorbic acid in calves. $25^{\text {th }}$ Annu. Rep. Sterility Res. Inst., R. Vet. Agric. Univ., Copenhagen, Denmark. p. 16.

Weiss, W. P., J. S. Hogan, and K. L. Smith. 2004. Changes in vitamin $C$ concentrations in plasma and milk from dairy cows after an intramammary infusion of Escherichia coli. J. Dairy Sci., 87(1): 32-37.

Wolf, G. 1993. Uptake of ascorbic acid by human neutrophils. Nutr. Rev., 51(11): 337-338.

Zee, J. A., L. Carmichael, D. Codere, D. Poirier, and M. Fournier. 1991. Effect of storage conditions on the stability of vitamin $C$ in various fruits and vegetables produced and consumed in Quebec. Journal of Food Composition and Analysis, 4(1): 77-86.

Zulkifli, I., M. T. Che-Norma, C. H. Chong, and T. C. Loh. 2000. Heterophil to hymphocyte ratio and tonic Immobility reactions to preslaughter handling in broiler chickens treates with ascorbic acid. Poultry Science, 79(3): 402-406. 